\title{
THE EFFECT OF IFRS ADOPTION AND LAW ENFORCEMENT ON BOOK TAX AGGRESSIVENESS: EVIDENCE FROM ASEAN COUNTRIES
}

\author{
Theresia Woro DAMAYANTI \\ Faculty of Economics and Business, Universitas Kristen Satya Wacana, Salatiga, Indonesia \\ E-mail:woro@staff.uksw.edu
}

Received 06 February 2019; accepted 18 April 2019

\begin{abstract}
Firms are arguably motivated to exhibit tax aggressiveness because tax constitutes a significant portion of firms' total costs. This study aims to test the effects of IFRS adoption and law enforcement on book-tax aggressiveness in six developing ASEAN countries. Our sample is 29,504 firm-year observations generated from Thomson Reuters Eikon for the years 2000-2017. The results show that IFRS adoption has a positive effect on book-tax aggressiveness, indicating that firms tend to prioritize book-tax aggressiveness over book-tax conformity. Further, law enforcement negatively affects book-tax aggressiveness. All in all, our findings imply that law enforcement is very crucial for ASEAN countries to enhance managers' awareness of not engaging the book-tax aggressiveness practice.
\end{abstract}

Keywords: tax reporting aggressiveness, financial reporting aggressiveness, IFRS, law enforcement.

JEL Classification: M41, H25, H26.

\section{Introduction}

Previous studies investigate how managers are confronted with a trade-off between book income and tax income (Badertscher et al. 2009, Balakrishnan et al. 2012, Watrin et al. 2012, Lennox et al. 2013). Maximizing book income (financial reporting aggressiveness) implies higher taxes. On the contrary, minimizing tax income (tax reporting aggressiveness) will lead to a lower book income. Thus, managers have to choose between financial and tax reporting aggressiveness. Ball and Shivakumar (2005), Watrin et al. (2012) demonstrate that managers prefer reducing tax income to save taxes by minimizing book income. However, Erickson et al. (2004) and Roxas (2016) indicate that firms are willing to pay higher taxes to report higher book income.

On the contrary, Chen et al. (2013), Kraft (2015), Fernandes et al. (2017) document that firms are not always confronted with a trade-off between financial reporting aggressiveness and tax reporting aggressiveness. Using booktax aggressiveness, Frank et al. (2009), Ko et al. (2012) and
Chen et al. (2013) show that firms that exhibit financial reporting aggressiveness are also tax-aggressive. Using former Arthur Andersen's clients that are highly aggressive in financial reporting, Heltzer et al. (2012) empirically demonstrate that these firms are also highly aggressive in tax reporting. Their findings are likely due to the accounting standard differences to prepare financial statements for investors' interests and fiscal-based financial statements (Whitaker 2005). The unconformities between accounting standards and tax rules provide opportunities for firms to report higher book income and lower tax income at the same time (Mills et al. 2002, Desai 2002).

Book-tax aggressiveness is closely related to accounting standard that increasingly facilitates firms to manage their book income without any consequence on taxable income (Hanlon 2005, Phillips et al. 2003). Currently, some countries have agreed to adopt International Financial Reporting Standards (IFRS) to harmonize these countries' accounting standards (Abdul-Majid 2017). IFRS adoption aims to enhance the quality, comparability, and convergence of

Copyright (C) 2019 The Authors. Published by VGTU Press.

This is an Open Access article distributed under the terms of the Creative Commons Attribution License (http://creativecommons.org/licenses/by/4.0/), which permits unrestricted use, distribution, and reproduction in any medium, provided the original author and source are credited.. 
accounting among countries (Barth et al. 2014, Cairns et al. 2011). However, IFRS' principle-based approach implies that firms have greater discretion to make subjective choices on accounting methods used (Okafor 2015, Blanchette et al. 2011). Thus, IFRS offers greater flexibility for firms to manage their book income (Nobes 2006, Christensen et al. 2013). Consequently, IFRS adoption increases booktax aggressiveness due to greater differences between accounting and tax rules (Chan et al. 2010). Previously, Ball (2006) also proposes that IFRS provides more opportunities for manipulative actions to manage book income. For example, Callao and Jarne (2010) empirically demonstrate that the IFRS adoption among European firms increases earnings management. In a similar vein, Chan et al. (2013), Karampinis and Hevas (2013), Chen and Gavious (2017) indicate that firms exhibit greater book-tax aggressiveness after the adoption of IFRS.

However, Tsalavoutas et al. (2010) show increased earnings quality after the adoption of IFRS. Barth et al. (2008) and Landsman et al. (2010) also demonstrate that IFRS adoption leads to more informative book earnings. Due to the cost and benefit considerations, some firms even do not make their accounting reports differently from tax reports. Furthermore, these firms even seek conformities between accounting and tax rules and not look for differences between these two rules (Rachmawati and Martani 2017). In this respect, Atwood et al. (2010) use the book-tax conformity term to represent a firm's conformity when reporting accounting income and fiscal income. Book-tax conformity is likely to reduce managers' opportunistic behavior in financial and tax reporting and reduce firms' compliance costs (Blaylock et al. 2015).

Okafor (2015) argues that the various effects of IFRS adoption on aggressiveness are due to the interaction with other factors. According to Chen and Gavious (2017), an important factor that affects the choice between book-tax aggressiveness or book-tax conformity is law enforcement. King and Sheffrin (2002) propose that the motivation to engage in tax aggressiveness is closely related to perceived justice and effectiveness in law enforcement. Wilhelm (2002) also holds that the effectiveness in law enforcement significantly affects tax compliance. In countries with effective law enforcement, taxpayers will comply with existing regulations, including tax and accounting regulations. Such compliance motivates taxpayers to engage in book-tax conformity.

This study aims to test the effects of IFRS adoption and law enforcement on firms' choice to engage in book-tax aggressiveness or book-tax conformity. We contribute to the literature by at least (1) extending previous studies that place a great emphasis on firms' tendency to engage in financial or tax reporting aggressiveness, and (2) using longer observation periods (2000-2017) and data from various developing countries that belong to the Association of Southeast Asian Nations (ASEAN).
This study aims to test the effects of IFRS adoption and law enforcement on firms' choice to engage in book-tax aggressiveness or book-tax conformity. We contribute to the literature by at least (1) expanding studies on the effect of IFRS on book-tax aggressiveness as a combination of financial reporting aggressiveness and tax reporting aggressiveness. Previous studies largely focus on the impact of IFRS on financial reporting aggressiveness (Ball 2006, JeanJean and Stolowy 2008, Christensen et al. 2013) or tax reporting aggressiveness (Desai 2005, Atwood et al. 2012, Chan et al. 2013, Tang 2015, Braga 2017) without combining these two issues. (2) using longer observation periods (2000-2017) and data from various developing countries that belong to the Association of Southeast Asian Nations (ASEAN) that enables us to analyze the varied effects of IFRS adoption in several countries through the law enforcement variable that has not been investigated before.

This study uses 29,504 publicly listed sample firms from Indonesia, Malaysia, Thailand, the Philippines, Singapore, and Vietnam as ASEAN member countries that have stock markets. Our observation period of 2000-2017 aims to avoid possible bias due to the 1998 Asian economic crisis. We measure book-tax aggressiveness by subtracting financial reporting aggressiveness with tax reporting aggressiveness. Further, financial reporting aggressiveness is measured with Modified-Jones model. By using panel data regression, this study demonstrates that IFRS adoption increases book-tax aggressiveness. Meanwhile, law enforcement enhances book-tax conformity. Thus, this study implies that law enforcement is crucial for ASEAN countries to minimize book-tax aggressiveness as a consequence of IFRS adoption.

This paper is organized as follows. Part 1 offers a brief literature review on the effects of IFRS adoption and law enforcement on firms' choice to engage in book-tax aggressiveness or book-tax conformity. Next, part 2 discusses the empirical models and data sources. Further, part 3 presents the results of the analysis and the discussions of the results. Finally, part 4 concludes and discusses the implications of this study.

\section{Literature review}

Shackelford and Sevlin (2001) observe that firms face a trade-off between financial and tax reporting aggressiveness. Erickson et al. (2004) support these findings by demonstrating that firms are willing to pay higher taxes to report higher income, because under the classical taxation system, the calculation of tax is based on profits (Kantsukov and Sander 2018). However, Kamila and Martani (2017) document that firms are not always confronted with a trade-off between financial reporting aggressiveness and tax reporting aggressiveness. Instead, firms also commit both types of aggressiveness at the same 
time (book-tax aggressiveness) or even conform accounting rules with tax rules (book-tax conformity).

There are two reasons why financial reporting aggressiveness is closely related to tax reporting aggressiveness. First, both are needed by firm managers at the same time. Specifically, managers commit tax reporting aggressiveness to maximize firm value (Kim et al. 2011) and financial reporting aggressiveness to enhance their managerial performance by increasing firms' profits. Second, the relationship between financial reporting aggressiveness and tax reporting aggressiveness is likely to be complementary. As suggested by Dhaliwal et al. (2008), when firms have specific income targets, they can use tax expense as a device to commit earnings management. Thus, several studies have observed that tax reporting aggressiveness affects financial reporting aggressiveness (Frank et al. 2009). Meanwhile, Lennox et al. (2013) find that financial reporting aggressiveness affects tax reporting aggressiveness.

IFRS aims to enhance the accuracy, transparency, and accessibility of financial statements to users of financial statements (Nulla 2014). However, IFRS adoption offers greater flexibility for firms to manage their book income because of its principle-based features (Christensen et al. 2013). These features cause accounting measurement to be more subjective and involve more managerial discretion (Callao and Jarne 2010). Rosen and Rosen (2009) even propose that rules in IFRS are very weak that lead to financial reporting aggressiveness such as revenue overstatement. Ball (2006) and JeanJean and Stolowy (2008) empirically support the argument by showing that IFRS adoption increases financial reporting aggressiveness.

Besides its effect on financial reporting aggressiveness, IFRS adoption also arguably affects tax reporting aggressiveness because tax reporting aggressiveness is closely related to accounting standards (Hanlon and Slemrod 2009, Braga 2017, Huang et al. 2018). After the IFRS adoption, the principles to prepare financial statements for commercial and fiscal purposes tend to be increasingly different. Specifically, the preparation of financial statements for commercial purposes is more principled-based while financial statements for fiscal purposes are realization-based. The increasingly greater differences between these two standards facilitate managers to engage in earnings management both for commercial and fiscal purposes (Huang et al. 2018). Even IFRS Bulletin documents exploratory evidence that tax authorities consider IFRS a potential cause of tax reporting aggressiveness (Okafor 2015). Previously, Lee (2010) finds that effective tax rates significantly decline after IFRS adoption in EU countries. The decline of effective tax rates indicates increased tax reporting aggressiveness. Several other studies also show that tax reporting aggressiveness increases after the adoption of IFRS (Chan et al. 2010, Atwood et al. 2012, Chan et al. 2013, Desai 2005, Tang 2015).
In short, besides increasing financial reporting aggressiveness, IFRS adoption also enhances tax reporting aggressiveness. Even Atwood et al. (2012) argue that financial reporting aggressiveness and tax reporting aggressiveness are two sides of the same coin because managers simultaneously aim to increase profits and reduce taxes. Chan et al. (2010), Chan et al. (2013), Karampinis and Hevas (2013), Chen and Gavious (2017) and Jiraskova (2015) document that IFRS adoption enlarges the difference between financial reporting for commercial and tax purposes. Thus, IFRS adoption increases the gaps between financial reporting aggressiveness and tax reporting aggressiveness (book-tax aggressiveness).

However, several studies observe that the opposite holds (book-tax conformity). Atwood et al. (2010) define booktax conformity as firms' conformity in reporting accounting and fiscal profits. In a similar vein, Frank et al. (2009) also empirically show the positive effect of financial reporting aggressiveness on tax reporting aggressiveness. In this respect, firms committing financial reporting aggressiveness are likely to exhibit greater tax reporting aggressiveness. On the contrary, the decisions not to commit financial reporting aggressiveness reduces tax reporting aggressiveness.

From the economic-financial point of view, the tax represents the fiscal relationship between the taxpayer and the government (Paulík et al. 2015, Dobrovič et al. 2018). Desai et al. (2007) develop an analytical model and demonstrate that law enforcement strengthens corporate governance mechanisms, build global competitiveness (Vaivode 2018) and eventually leads to lower tax reporting aggressiveness. Zeng and Zhang (2009), Ye and Liu (2011), also Jiang (2013) also find similar results. Further, using Chinese listed firms, Ye and Liu (2011) empirically demonstrate that the better law enforcement, the more difficult for firms to engage in financial reporting aggressiveness, let alone tax reporting aggressiveness. Lastly, Wang (2015) documents a greater tax aggressiveness difference in areas with worse law enforcement. In countries with better (worse) law enforcement, taxpayers are more (less) likely to comply with existing rules, including tax and accounting ones, and eventually commit book-tax conformity (aggressiveness).

\section{Research method}

This study uses publicly listed firms in ASEAN countries for the years 2000-2017 as the sample. The observation periods of 2000-2017 are selected because these years were arguably not affected by the Asian economic crisis in 1998. There are six ASEAN countries that have stock markets, namely Indonesia, Malaysia, Thailand, the Philippines, Singapore, and Vietnam. This study generates financial data from Thomson Reuters Eikon. The dependent variable book-tax aggressiveness is measured by subtracting financial 
reporting aggressiveness with tax reporting aggressiveness. A higher (lower) difference between financial reporting aggressiveness and tax reporting aggressiveness indicates book-tax aggressiveness (conformity).

This study measures financial reporting aggressiveness using the following Modified-Jones model (Dechow et al. 1995)

$$
\mathrm{TACC}=\alpha+\alpha(\Delta \mathrm{REV}-\Delta \mathrm{AR})+\alpha \mathrm{PPE}+\eta,
$$

where TACC represents total accrual that is measured by $(\mathrm{EBEI}+\mathrm{TTE})-((\mathrm{CFO}+\mathrm{ITP})-\mathrm{EIDO}), \alpha$ (the intercept of the model), EBEI refers to earnings before extraordinary items from statement of cash flows, TTE is total tax expense, CFO is cash flow from operation, ITP refers to income tax paid from statement cash flows, and EIDO is extraordinary items and discontinued operation from statement of cash flows. Meanwhile, $\triangle \mathrm{REV}$ represents a change in sales and $\triangle \mathrm{AR}$ is a change in account receivables. Lastly, PPE is property plant and equipment.

For tax reporting aggressiveness, this study uses the following equation as suggested by Frank et al. (2009):

$$
\begin{gathered}
\text { PERMDIFF }=\alpha+\alpha \text { INTANG }+\alpha \text { UNCON }+\alpha M I+ \\
\alpha \text { CSTE }+\alpha \Delta \text { NOL }+\alpha \text { LAGPERM }+\varepsilon,
\end{gathered}
$$

where PERMDIFF is total book-tax differences - temporary book-tax differences ((BI - ((CTFE + CFOR)/ STR)) -(DTE/STR) divided by total asset, BI represents pretax book income, CTFE refers to current federal tax expense, CFOR is current foreign tax expense, DTE is deferred tax expense, and STR refers to the statutory tax rate. Further, INTANG is goodwill or other intangibles divided by total asset year $\mathrm{t}-1$, UNCON represents income (loss) divided by tax asset year $\mathrm{t}-1, \mathrm{MI}$ is income (loss) attributable to minority interest divided by tax asset year $\mathrm{t}-1$, CSTE refers to current income tax expense divided by tax asset year $t-1, \Delta N O L$ is a change in net operating loss carryforward divided by tax asset year $\mathrm{t}-1$ and LAGPERM is PERMDIFF at year $\mathrm{t}-1$ divided by tax asset year $\mathrm{t}-1$.

We measure book-tax aggressiveness by using two alternative proxies: (1) the absolute value of the difference between financial reporting aggressiveness and tax reporting aggressiveness and (2) a dummy variable that equals to one (zero) if a firm-year observation exhibits book-tax aggressiveness (book-tax conformity). The independent variables are IFRS adoption and the effectiveness of law enforcement. The measurement of the effectiveness of law enforcement relies on Transparency International's Corruption Perception Index scores (CPI). This study employs three control variables, namely firm size, profitability, and growth. Previous studies have shown that these control variables affect earnings management (Beneish 1999, Koh and Lee 2015).

This study generates 2,496 sample firms for the observation period of 2000-2017. Because of the data availability issue, we have to leave out some firm-year observations from our sample that produces the final unbalanced panel data of 29,504 firm-year observations. Table 1 below explains the number of sample for each country.

Table 1 suggests that Malaysia has the largest proportions of the firm and firm-year observations while the Philippine the lowest. Further, the six ASEAN countries adopted IFRS in different years. Indonesia and Malaysia have fully adopted IFRS since 2012 but the preparation began in 2008. Meanwhile, the Philippines launched the preparation of the adoption in 2009 and fully adopted IFRS in 2014. Singapore fully adopted IFRS in 2018 and started the adoption in 2015. Starting the adoption in 2011, Thailand fully adopted IFRS in 2013. Lastly, Vietnam started the adoption since 2003.

This study uses the panel data regression to test the effects of IFRS adoption and law enforcement on firms' choice to engage in book-tax aggressiveness or book-tax conformity. The test starts with the data stationary test and the selection of the best estimator model (using the Chow test, Hausman test, and Lagrange Multiplier). Afterward, the test analyzes the effects of IFRS adoption and law enforcement on book-tax aggressiveness. Finally, we run the robustness test by analyzing the effect of IFRS on book-tax aggressiveness based in two subsamples based on the level of law enforcement (low if CPI is $\leq 5$ and high if CPI is between 5 and 10).

Table 1. Firm-year sample (by country) (source: Thomson Reuters Eikon)

\begin{tabular}{|l|c|c|c|c|c|c|}
\hline \multirow{2}{*}{ Country } & \multicolumn{3}{|c|}{ Sample Firms } & \multicolumn{2}{c|}{ The IFRS Adoption Phase } \\
\cline { 2 - 7 } & Number of Firms & $\%$ & Firm-Year Obs. & $\%$ & Initial Phase & Full Phase \\
\hline Indonesia & 288 & $11.54 \%$ & 3.048 & $10.33 \%$ & 2008 & 2012 \\
\hline Malaysia & 579 & $23.20 \%$ & 8.461 & $28.68 \%$ & 2008 & 2012 \\
\hline Philippines & 139 & $5.57 \%$ & 1.816 & $6.16 \%$ & 2009 & 2014 \\
\hline Singapore & 371 & $14.86 \%$ & 5.308 & $17.99 \%$ & 2015 & 2018 \\
\hline Thailand & 429 & $17.19 \%$ & 5.087 & $17.24 \%$ & 2011 & 2013 \\
\hline Vietnam & 690 & $27.64 \%$ & 5.784 & $19.60 \%$ & 2003 & \\
\hline Total & 2496 & $100 \%$ & 29.504 & $100 \%$ & & \\
\hline
\end{tabular}




\section{Results and discussion}

Table 2 displays the mean values of the research variables using 29,504 firm-year observations in six ASEAN countries. The table suggests that Vietnam (24.92), Indonesia (17.40) and the Philippines (8.74) exhibit the mean values of the book-tax variable greater than that of all ASEAN countries. The figures indicate that these three countries are likely to engage in greater book-tax aggressiveness than Singapore, Malaysia, and Thailand that tend to exhibit tax-book conformity. Using the Transparency International's Corruption Perception Index (CPI) scores as the proxy of law enforcement, we show that Singapore (9.00) and Malaysia (4.92) have the highest law enforcement scores among all ASEAN countries. The figures suggest that these two countries exhibit greater law enforcement relative to the four other countries. Further, the law enforcement score with a range of 1-10 indicates that only Singapore that has a very high law enforcement score. For the control variables, Table 2 indicates that Singapore and Thailand have greater mean values of firm size than that of all ASEAN countries. Further, firms in Malaysia, the Philippines, Singapore, and Thailand exhibit higher profitability than that of all ASEAN countries. Lastly, firms in Indonesia and the Philippines have greater growth than firms in all ASEAN countries.

Table 2. The mean values of the research variables per country (secondary data, processed)

\begin{tabular}{|l|c|c|c|c|c|}
\hline Country & $\begin{array}{c}\text { Book-Tax } \\
\text { Aggres- } \\
\text { siveness }\end{array}$ & $\begin{array}{c}\text { Law } \\
\text { enfor- } \\
\text { cement }\end{array}$ & $\begin{array}{c}\text { Firm } \\
\text { Size }\end{array}$ & $\begin{array}{c}\text { Profit- } \\
\text { ability }\end{array}$ & Growth \\
\hline Indonesia & 17.40 & 2.98 & 0.34 & 0.11 & 0.57 \\
\hline Malaysia & 3.44 & 4.92 & 0.24 & 0.27 & 0.14 \\
\hline Philippines & 8.74 & 2.96 & 0.14 & 0.19 & 0.31 \\
\hline Singapore & 1.70 & 9.00 & 0.61 & 0.23 & 0.25 \\
\hline Thailand & 4.80 & 3.54 & 0.42 & 0.21 & 0.21 \\
\hline Vietnam & 24.92 & 3.01 & 0.33 & 0.15 & 0.22 \\
\hline $\begin{array}{l}\text { All } \\
\text { Country }\end{array}$ & 6.91 & 4.72 & 0.35 & 0.17 & 0.29 \\
\hline
\end{tabular}

Notes: Book Tax Agresiveness = financial reporting aggressiveness - tax reporting aggressiveness, Size $=$ total property plant and equipment/total assets; Profitability = net income $/$ total assets and Growth $=\left(\right.$ sales $_{\mathrm{t}}-$ sales $\left._{\mathrm{t}-1}\right) /$ sales $_{\mathrm{t}-1}$.

For the control variables, the table indicates that Singapore and Thailand have greater mean values of firm size than that of all ASEAN countries Malaysia and the Philippines are countries with the smallest firm size. Further, Malaysia, Philippines, Singapore, and Thailand exhibit higher profitability than that of all ASEAN countries. Lastly, firms in Indonesia and the Philippines have greater growth than firms in all ASEAN countries.
Before empirically analyzing the data, we initially run the data stationary test to avoid spurious regression problem by analyzing the data validity and stability. Table 3 shows that size, profitability, and IFRS adoption are stable at the integration level or at $\mathrm{I}(0)$, as indicated by the probability value that is less than the critical value ( $\alpha=5 \%)$. Meanwhile, growth is not stationary at the integration level, implying that we have to run the first difference principle (first-order). The first-order differentiation or I(1) suggests that the integration level is stationary as indicated by the probabilistic value that is less than the critical value $(\alpha=5 \%)$.

Table 3. The Results of Panel Data Stationary Test (secondary data, processed)

\begin{tabular}{|l|c|c|c|}
\hline \multirow{2}{*}{\multicolumn{1}{c|}{ Variable }} & \multicolumn{2}{|c|}{ Probability } & \multirow{2}{*}{ Conclusion } \\
\cline { 2 - 3 } & Levin Test & $\begin{array}{c}\text { Phillips- } \\
\text { Perron Test }\end{array}$ & \\
\hline IFRS Adoption & 0.000 & 0.000 & $\mathrm{I}(0)$ \\
\hline Size & 0.000 & 0.000 & $\mathrm{I}(0)$ \\
\hline Profitability & 0.000 & 0.000 & $\mathrm{I}(0)$ \\
\hline Growth & 0.005 & 0.043 & $\mathrm{I}(1)$ \\
\hline
\end{tabular}

The results of the Chow Test, Hausman Test, and Lagrange Multiplier Test show that the random effect is appropriate for this study. In the random effect, the Ordinary Least Square (OLS) is not suitable to generate efficient estimators. Thus, the appropriate method is the Generalized Least Squares (GLS). The homoskedasticity and no cross-sectional correlation assumptions imply that the heteroskedasticity test is no longer necessary in the random effect test (Table 4).

Table 4. The Results of the Random Effect Model Test (secondary data, processed)

\begin{tabular}{|l|c|c|c|}
\hline \multicolumn{1}{|c|}{ Panel A. Testing of Best Estimation Model } \\
\hline Thow Test & Prob & \multicolumn{2}{l|}{ Best Estimation Model } \\
\hline Hausman Test & 0.983 & \multicolumn{2}{l|}{ Common Effects } \\
\hline $\begin{array}{l}\text { Lagrange } \\
\text { Multiplier Test }\end{array}$ & 0.003 & \multicolumn{2}{l|}{ Random effects } \\
\hline Panel B Data Analysis & Coefficient & t-statistic & Prob. \\
\hline \multicolumn{1}{|c|}{ Variable } & 10778557 & 5.790 & $0.000^{* * *}$ \\
\hline c & 14065661 & 2.716 & $0.007^{* * *}$ \\
\hline IFRS Adoption & -497069.5 & -2.957 & $0.003^{* * *}$ \\
\hline $\begin{array}{l}\text { Law } \\
\text { Enforcement }\end{array}$ & 727343.7 & 2.516 & $0.012^{* *}$ \\
\hline Size & -44.262 & -4.913 & $0.000^{* * *}$ \\
\hline Profitability & 9.391 & 5.397 & $0.000^{* * *}$ \\
\hline Growth & 0.000 & & \\
\hline F-Statistics &
\end{tabular}

Notes: ${ }^{*} p<0.1 ;{ }^{* *} p<0.05 ;{ }^{* *} p<0.01 \%$. 
The analysis demonstrates that IFRS adoption has a significant effect on book-tax aggressiveness ( $p=0.007<\alpha 1 \%)$. The positive coefficient suggests that IFRS adoption increases book-tax aggressiveness. Meanwhile, law enforcement exhibits a significant effect with the contrary direction. Specifically, with the probability value below $\alpha=1 \%$ and a negative coefficient value, law enforcement reduces book-tax aggressiveness or leads to book-tax conformity. The control variables (size, profitability, and growth) also significantly affect book-tax aggressiveness. The positive coefficients of size and growth imply that firms with larger size and higher sales growth tend to engage in book-tax aggressiveness. Further, the negative coefficient of profitability shows that greater profitability is associated with book-tax conformity.

As an alternative test, we also develop a dummy variable to investigate the impacts of IFRS adoption and law enforcement on book-tax aggressiveness. The dummy variable is equal to one if a firm-year engage in book-tax aggressiveness and zero if the firm-year commit book-tax conformity. Our alternative test produces qualitatively similar results. Specifically, IFRS adoption increases book-tax aggressiveness while law enforcement increases book-tax conformity. Further, size and growth (profitability) also have positive (negative) coefficients, suggesting that firms with larger size and higher sales growth tend to commit book-tax aggressiveness while highly profitable firms tend to exhibit book-tax conformity.

Table 5. The Results of the Random Effect Model Test (Dummy)

\begin{tabular}{|l|c|c|c|}
\hline \multicolumn{1}{|c|}{ Variable } & Coefficient & t-statistic & Prob. \\
\hline c & 1.122620 & 34.06225 & $0.0000^{\star * *}$ \\
\hline $\begin{array}{l}\text { Law } \\
\text { Enforcement }\end{array}$ & -0.180409 & -26.11171 & $0.0006^{* * *}$ \\
\hline $\begin{array}{l}\text { Adoption of } \\
\text { IFRS }\end{array}$ & 0.064868 & 4.151756 & $0.0000^{\star * *}$ \\
\hline Size & 3.56723 & 1.713653 & $0.0867^{*}$ \\
\hline Profitability & -3.5421 & -3.449889 & $0.0006^{* * *}$ \\
\hline Growth & 1.18765 & 6.993801 & $0.0000^{\star * *}$ \\
\hline F-Statistics & 0.0000 & & \\
\hline
\end{tabular}

Notes: ${ }^{*} p<0.1 ;{ }^{* *} p<0.05 ;{ }^{* *} p<0.01 \%$.

This study (Table 5) demonstrates that after the IFRS adoption, the accounting principle differences to report book income and tax income enhance book-tax aggressiveness. Financial statements to report book income is more principle-based while tax financial statements are realization-based. The difference offers greater discretion for managers to select accounting methods for both purposes because these two principles are weakly related. Thus, managers have more freedom to minimize tax expense without having to face the dilemma of reducing book income that will eventually increase book-tax aggressiveness.
Chan et al. (2013), Karampinis and Hevas (2013) and Chen and Gavious (2017) who find that firms exhibit greater differences between financial statements for commercial and fiscal purposes in the post-IFRS adoption years.

However, this study also suggests that in countries with high law enforcement, firms are likely to exhibit book-tax conformity although they have greater flexibility to engage in earnings management both for commercial and fiscal purposes. We argue that firms in such countries will comply with rules and regulations, including tax and accounting ones. The findings also support Zeng and Zhang (2009), Ye and Liu (2011), Jiang (2013) who demonstrate that better law enforcement causes taxpayers to opt for book-tax conformity.

We also run another sensitivity test by analyzing the effect of IFRS adoption on book-tax aggressiveness by splitting our sample into two subsamples based on the level of countries' law enforcement (low vs. high law enforcement). This test aims to investigate whether a better quality of law enforcement reduces the effect of IFRS adoption on booktax aggressiveness.

Table 6. The results of the random effect model test - splitting sample based on the level of law enforcement

\begin{tabular}{|c|c|c|c|c|}
\hline \multicolumn{5}{|c|}{$\begin{array}{l}\text { Panel A. Dependent Variable Book-Tax Aggressiveness } \\
\text { (Absolute) }\end{array}$} \\
\hline & \multicolumn{2}{|c|}{ High Law Enforcement } & \multicolumn{2}{|c|}{ Low Law Enforcement } \\
\hline Variable & Coefficient & Prob. & Coefficient & Prob. \\
\hline c & 488357 & $0.000^{* * *}$ & 1136277 & $0.000^{\star * \star}$ \\
\hline $\begin{array}{l}\text { Adoption } \\
\text { of IFRS }\end{array}$ & 1067197 & 0.778 & 85381299 & $0.000^{* * *}$ \\
\hline Size & 0.061 & $0.000^{* * *}$ & $6.35 \mathrm{E}-08$ & $0.000^{* * *}$ \\
\hline Profitability & 1.365 & $0.000^{* * *}$ & 1.637394 & $0.000^{* * *}$ \\
\hline Growth & -0.185 & $0.000^{* * *}$ & $9.33 \mathrm{E}-07$ & $0.000^{* * *}$ \\
\hline \multicolumn{5}{|c|}{$\begin{array}{l}\text { Panel B. Dependent Variabel Book Tax Aggressiveness } \\
\text { (Dummy) }\end{array}$} \\
\hline & \multicolumn{2}{|c|}{ High Law Enforcement } & \multicolumn{2}{|c|}{ Low Law Enforcement } \\
\hline Variable & Coefficient & Prob. & Coefficient & Prob. \\
\hline c & 0.006910 & $0.000^{* * *}$ & 0.350980 & $0.0000^{* * *}$ \\
\hline $\begin{array}{l}\text { Adoption } \\
\text { of IFRS }\end{array}$ & -0.030748 & $0.000^{* * *}$ & 0.148757 & $0.0000^{* * *}$ \\
\hline Size & $1.78 \mathrm{E}-10$ & $0.000^{* * *}$ & $6.59 \mathrm{E}-18$ & $0.0000^{* * *}$ \\
\hline Profitability & $4.21 \mathrm{E}-09$ & $0.000^{* * *}$ & $1.26 \mathrm{E}-11$ & $0.0000^{* * *}$ \\
\hline Growth & $-1.42 \mathrm{E}-09$ & $0.000^{* * *}$ & $1.19 \mathrm{E}-17$ & $0.0000^{* * *}$ \\
\hline
\end{tabular}

Table 6 above displays the different effects of IFRS adoption on book-tax aggressiveness. Using the absolute values of book-tax aggressiveness, Panel A shows that when law enforcement is highly effective, IFRS adoption has no effect on book-tax aggressiveness or book-tax conformity (probability value above $\alpha$ ). However, when law enforcement is ineffective, IFRS adoption exhibits a significant impact on 
book-tax aggressiveness (probability value $<\alpha 1 \%$ ). The positive coefficient suggests that IFRS adoption increases book-tax aggressiveness when the quality of law enforcement is low.

Panel B that uses a dummy variable to represent booktax aggressiveness shows similar results. When law enforcement is highly effective, IFRS adoption significantly affects book-tax aggressiveness (probability value $<\alpha=1 \%$.). The negative coefficient implies that when the quality of law enforcement is high, IFRS adoption is likely to increase booktax conformity. On the contrary, when law enforcement is less effective, IFRS adoption significantly affects book-tax aggressiveness. The positive coefficient value implies that IFRS adoption increases book-tax aggressiveness when the quality of law enforcement is low.

Our results support Okafor (2015) who observe the varied effects of IFRS adoption on aggressiveness. Specifically, this study demonstrates that IFRS adoption has different effects on aggressiveness based on law enforcement. When law enforcement is highly effective, there is no effect of IFRS adoption on book-tax aggressiveness. IFRS adoption even leads to book-tax conformity. However, when the quality of law enforcement is low, IFRS adoption increases book-tax aggressiveness. Further, our findings are also in line with Chen and Gavious (2017) who show that law enforcement is one of the several factors that explain the variation in the effect of IFRS adoption on aggressiveness.

\section{Conclusions and recommendation}

This study aims to test the effects of IFRS adoption and law enforcement on book-tax aggressiveness (book-tax conformity) in six developing countries that belong to ASEAN, namely Indonesia, Malaysia, Thailand, the Philippines, Singapore, and Vietnam. This study shows that IFRS adoption in six developing countries that belong to ASEAN have an effect on book-tax aggressiveness. IFRS gives firms greater flexibility to minimize tax expense without having to report lower book income. Thus, firms can minimize their tax income and manage their earnings at the same time. This opportunity may motivate managers to engage in book-tax aggressiveness. This study also suggests law enforcement negatively affects book-tax aggressiveness. In countries that consistently enforce their laws, firms as corporate taxpayers are more likely to comply with various regulations, including tax and accounting rules, and eventually to avoid book-tax aggressiveness. On the contrary, firms in these countries will arguably commit book-tax conformity by reporting accounting income that is similar to fiscal income.

This study indicates that IFRS adoption enhances book-tax aggressiveness. Thus, the results are in line with Karampinis and Hevas (2013) and Chen and Gavious (2017) that find that the differences between commercial and fiscal financial statements. Our results also support Okafor (2015) and Chen and Gavious (2017) that highlight varied impacts of IFRS adoption on aggressiveness with law enforcement as a likely explanation.

Overall, this study recommends that law enforcement is crucial for ASEAN countries to enhance firms' awareness to avoid book-tax aggressiveness practice. If the governments of these countries enforce their laws consistently, they will arguably manage to minimize firms' greater flexibility to report aggressively for both earnings management and taxation purposes due to the adoption of IFRS.

This study only used company characteristics as a control variable, and has not considered the characteristics of the company's top management as decision makers, including decisions about tax aggressiveness. While in previous studies shows that the characteristics of the company's top management can influence tax aggressiveness. Future studies can consider adding the characteristics of the company's top management such as age, gender, education and risk preference as control variables in relation to tax aggressiveness.

\section{Disclosure statement}

Author declare that they have no competing financial, professional, or personal interests from other parties.

\section{References}

Abdul-Majid J (2017) Audit committee independence and a contracting perspective on good will impairment: Singaporean Evidence. Business: Theory and Practice 18: 128-135. https://doi.org/10.3846/btp.2017.013

Atwood TJ, Drake M, Myers LA (2010) Book-tax conformity, earnings persistence and the association between earnings and future cash flows. Journal of Accounting and Economics 50: 111-125. https://doi.org/10.1016/j.jacceco.2009.11.001

Atwood TJ, Drake MS, Myers JN, Myers LA (2012) Home country tax system characteristics and corporate tax avoidance: international evidence. The Accounting Review 87 (6): 1831-1860. https://doi.org/10.2308/accr-50222

Badertscher BA, Phillips JD, Pincus M, Rego SO (2009) earnings management strategies and the trade-off between tax benefits and detection risk: to conform or not to conform? The Accounting Review 84 (1): 63-97. https://doi.org/10.2308/accr.2009.84.1.63

Balakrishnan K, Blouin J, Guay WR (2012) Tax aggressiveness and corporate transparency https://ssrn.com/abstract=1792783

Ball R, Shivakumar L (2005) Earnings quality in UK private firms: comparative loss recognition timeliness. Journal of Accounting and Economics 39: 83-128. https://doi.org/10.1016/j.jacceco.2004.04.001

Ball R (2006) International financial reporting standards (IFRS): Pros and cons for investors. Accounting and Business Research 36 (1): 5-27. https://doi.org/10.1080/00014788.2006.9730040 
Barth ME, Landsman WR, Lang MH (2008) International accounting standards and accounting quality. Journal of Accounting Research 46 (3): 467-498. https://doi.org/10.1111/j.1475-679X.2008.00287.x

Beneish M (1999) Incentives and penalties related to earnings overstatements that violate GAAP. The Accounting Review 74 (4): 425-457. https://doi.org/10.2308/accr.1999.74.4.425

Blaylock BS, Shevlin TJ, Gaertner FB (2015) The Association between book-tax conformity and earnings. Management Review of Accounting Studies 20 (1): 141-172. https://doi.org/10.2139/ssrn.1983107

Blanchette M, Racicot F, Girard J (2011) The Effects of IFRS on financial ratios: early evidence in Canada. Certified General Accountants Association of Canada http://www.cga-canada. org/enca/ResearchReports/ca_rep_2011-03_IFRS_early_ adopters.pdf

Braga RN (2017) Effects of IFRS adoption on tax avoidance. Revista Contabilidade \& Finanças 28 (75): 407-424. https://doi.org/10.1590/1808-057x201704680

Cairns D, Massoudi D, Taplin R, Tarca A (2011) FRS fair value measurement and accounting policy choice in the United Kingdom and Australia. The British Accounting Review 43: 1-21. https://doi.org/10.1016/j.bar.2010.10.003

Callao S, Jarne J (2010) Have IFR S affected earnings management in the European Union? Accounting in Europe 7 (2): 159-189. https://doi.org/10.1080/17449480.2010.511896

Chan KH, Lin KZ, Mo PLL (2010) Will a departure from taxbased accounting encourage tax noncompliance? Archival evidence from a transitory economy. Journal of Accounting and Economics 50: 58-73.

https://doi.org/10.1016/j.jacceco.2010.02.001

Chan KH, Lin KZ, Tang F (2013) Tax effects of book-tax conformity, financial reporting incentives, and firm size. Journal of International Accounting Research 12 (2): 1-25. https://doi.org/10.2308/jiar-50404

Chen E, Gavious I, Yosef R (2013) The relationship between the management of book income and taxable income under a moderate level of book-tax conformity. Journal of Accounting, Auditing \& Finance 28 (4): 323-347.

https://doi.org/10.1177/0148558X13505591

Chen E, Gavious I (2017) The roles of book-tax conformity and tax enforcement in regulating tax reporting behavior following International Financial Reporting Standards adoption. Accounting and Finance 57 (3): 681-699. https://doi.org/10.1111/acfi.12172

Christensen H, Hail L, Leuz C (2013) Mandatory IFRS reporting and changes in enforcement. Journal of Accounting and Economics 56 (2): 147-177. https://doi.org/10.1016/j.jacceco.2013.10.007

Dhaliwal DS, Huber R, Lee HS, Pincus M (2008) Book-tax differences, uncertainty about fundamentals and information quality, and cost of capital https://ssrn.com/abstract=1127956

Dechow P, Sloan R, Sweeney A (1995) Detecting earnings management. The Accounting Review 70 (2): 193-226.

Desai M (2002) The divergence between book and tax income. Tax Policy and the Economy 17 (1): 169-206.

https://doi.org/10.1086/tpe.17.20140508
Desai M (2005) The degradation of reported corporate profits. The Journal of Economic Perspectives 19: 171-193. https://doi.org/10.2139/ssrn.758144

Desai MA, Dyck A, Zingales L (2007) Theft and taxes. Journal of Financial Economics 84 (3): 591-623. https://doi.org/10.1016/j.jfineco.2006.05.005

Dobrovič J, Gombár M, Ali Taha V (2018) Forms of managing the efficiency of tax administration in Slovak Republic. Journal of International Studies 11 (2): 304-314. https://doi.org/10.14254/2071-8330.2018/11-2/20

Erickson M, Hanlon M, Maydew E (2004) How much will firms pay for earnings that do not exist?: Evidence of taxes paid on allegedly fraudulent earnings. The Accounting Review 79 (2): 387-408. https://doi.org/10.2139/ssrn.347420

Frank MM, Lynch LJ, Rego SO (2009) Tax reporting aggressiveness and its relation to aggressive financial reporting. The Accounting Review 84 (2): 467-496. https://doi.org/10.2308/accr.2009.84.2.467

Fernandes A, Cerqueira A, Brandao E (2017) Tax and financial reporting aggressiveness: evidence from Europe. FEP Working Papers, School of Economics and Management, University of Porto.

Hanlon M (2005) The persistence and pricing of earnings, accruals, and cash flows when firms have large book-tax differences. The Accounting Review 80 (1): 137-166. https://doi.org/10.2308/accr.2005.80.1.137

Hanlon M, Slemrod J (2009) What does tax aggressiveness signal? Evidence from stock market reaction to news about tax shelter involvement. Journal of Public Economics 93: 126-141. https://doi.org/10.1016/j.jpubeco.2008.09.004

Heltzer W, Mindak MP, Shelton SW (2012) The relation between aggressive financial reporting and aggressive tax reporting: Evidence from ex-Arthur Andersen clients. Research in Accounting Regulation 24 (2): 96-104. https://doi.org/10.1016/j.racreg.2012.05.001

Huang M, Chen H, Rickards RC (2018) The effects of IFRS adoption on tax avoidance in Europe. Journal of Management and Business Research 35 (1): 57-78.

Jeanjean T, Stolowy H (2008) Do accounting standards matter? An exploratory analysis of earnings management before and after IFRS adoption. Journal of Accounting and Public Policy 27: 480-494. https://doi.org/10.1016/j.jaccpubpol.2008.09.008

Jiang XY (2013) Tax enforcement, tax aggressiveness and stock price crash risk. Nankai Business Review 5: 152-160. https://doi.org/10.2139/ssrn.3105186

Jiraskova S (2015) The relationship between tax and book income after adoption IFRS in the Czech Republic in comparison with other European Countries. Journal of Economics, Business and Management 3 (12): 1180-1184. https://doi.org/10.7763/JOEBM.2015.V3.355

Kamila PA, Martani D (2017) Analisis Hubungan Agresivitas Pelaporan Keuangan Dan Agresivitas Pajak. Jurnal Keuangan dan Perbankan 16 (2).

Kantsukov M, Sander P (2018) A less in valuation from Estonia: The difference between the fundamental value of equity under distributed and traditional profit taxation system. Business: Theory and Practice 19: 146-156. https://doi.org/10.3846/btp.2018.15 
Karampinis N, Hevas DL (2013) Effects of IFRS Adoption on Tax-induced Incentives for Financial Earnings Management: Evidence from Greece. The International Journal of Accounting 48 (2): 218-247. https://doi.org/10.1016/j.intacc.2013.04.003

Kim JB, Li, Zhang L (2011) Corporate tax avoidance and stock price crash risk: firm-level analysis. Journal of Financial Economics 100: 639-662. https://doi.org/10.1016/j.jfineco.2010.07.007

King S, Sheffrin SM (2002) Tax evasion and equity theory: an investigative approach. International Tax and Public Finance 9: 505-521. https://doi.org/10.1023/A:1016528406214

Ko JK, Choi EH, Kim WY (2012) The relation between aggressive financial reporting and aggressive tax reporting: Korean evidence. Korean Accounting Journal 21 (3): 95-130.

Koh Y, Lee H-A (2015) The effect of financial factors on firms' financial and tax reporting decisions. Asian Review of Accounting 23 (2): 110-138. https://doi.org/10.1108/ARA-01-2014-0016

Kraft A (2015) Management earnings forecasts and book-tax differences. International Journal of Economics and Finance 7 (3): 1-23. https://doi.org/10.5539/ijef.v7n3p1

Landsman WR, Maydew EL, Thornock JR (2012) The information content of annual earnings announcements and mandatory adoption of IFRS. Journal of Accounting and Economics 53 (1): 34-54. https://doi.org/10.1016/j.jacceco.2011.04.002

Lee N (2010) Shock and law: Fin 48 Report Card, IFRS and beyond. International Journal of Economics and Finance 2 (3): 222-233. https://doi.org/10.5539/ijef.v2n3p222

Lennox C, Lisowsky P, Pittman J (2013) Tax aggressiveness and accounting fraud. Journal of Accounting Research 51 (4): 739-778. https://doi.org/10.1111/joar.12002

Mills L, Newberry K, Trautman W (2002) Trends in book-tax income and balance sheet differences. Tax Notes 19: 11091124. https://doi.org/10.2139/ssrn.313040

Nobes C (2006) The survival of international differences under IFRS: towards a research agenda. Accounting Bussiness Research 36: 233-245. https://doi.org/10.1080/00014788.2006.9730023

Nulla YM (2014) Does IFRS adoption influence quality of reporting?: An empirical evidence from large Canadian banks. International Journal of Accounting and Taxation 2 (2): 85-109.

Okafor ON (2015) Effects of IFRS on accounting quality and tax aggressiveness: evidence from Canadian mandatory adoption. University of Calgary.

Paulík J, Kombo F, Ključnikov A (2015) CSR as a driver of satisfaction and loyalty in commercial banks in the Czech Republic. Journal of International Studies 8 (3): 112-127. https://doi.org/10.14254/2071-8330.2015/8-2/15
Phillips J, Pincus M, Rego S (2003) Earnings management: New evidence based on deferred tax expense. The Accounting Review 78 (2): 491-521. https://doi.org/10.2308/accr.2003.78.2.491

Rachmawati NA, Martani D (2017) Book-tax conformity level on the relationship between tax reporting aggressiveness and financial reporting aggressiveness. Australasian Accounting, Business and Finance Journal 11 (4): 86-101. https://doi.org/10.14453/aabf.v11i4.7

Rosen A, Rosen M (2009) Critics speak out as IFRS looms: Charest latest to criticize vague new rules. Financial Post http://www. rosen-associates.com/pdf/09_May13_Critics\%20speak\%20 out\%20as\%20IFRS\%20looms.pdf

Roxas ML (2016) Additional evidence of firms' willingness to pay taxes on apparent fictitious earnings. Journal of Applied Business and Economics 18 (6):112-117.

Shackelford DA, Shevlin T (2001) Empirical tax research in accounting. Journal of Accounting and Economics 31: 321387. https://doi.org/10.1016/S0165-4101(01)00022-2

Tsalavoutas I, Andre P, Evans L (2012) The transition to IFRS and the value relevance of financial statements in Greece. British Accounting Review 44 (4): 262-277. https://doi.org/10.1016/j.bar.2012.09.004

Tang TYH (2015) Does book-tax conformity deter opportunistic book and tax reporting? An international analysis. European Accounting Review 24 (3): 441-469.

https://doi.org/10.1080/09638180.2014.932297

Vaivode I (2018) Born global companies. Is this a future economy of Latvia? A preliminary study. Business: Theory and Practice 19: 288-299. https://doi.org/10.3846/btp.2018.29

Wang L (2015) Tax enforcement, corporate tax aggressiveness, and cash holdings. China Finance Review International 5 (4): 339-370. https://doi.org/10.1108/CFRI-12-2014-0099

Watrin C, Pott C, Ullman R (2012) The effect of book - tax conformity and tax accounting incentives on financial accounting: evidence from public and private limited companies in Germany. International Journal of Accounting Auditing and Performance Evaluation 8 (3): 274-302. https://doi.org/10.1504/IJAAPE.2012.047811

Whitaker C (2005) Bridging the book - tax accounting gap. Yale Law Journal 115 (3): 680-726.

Wilhelm PG (2002) International validation of the corruption perceptions index: Implications for business ethics and entrepreneurship education. Journal of Business Ethics 35 (3): 177-189. https://doi.org/10.1023/A:1013882225402

Ye KT, Liu H (2011) Tax enforcement, income tax costs, and earnings management. Management World 5: 140-148.

Zeng YM, Zhang JS (2009) Does tax enforcement play a role as a corporate governance mechanism. Management World 3: 143-151. 